\title{
Early growth evaluation and estimation of heritability in a sengon (Falcataria moluccana) progeny testing at Kediri, East Java, Indonesia
}

\author{
ADITYA NUGROHO ${ }^{1, \vartheta}$, DEDEN D. MATRA ${ }^{2}$, ISKANDAR Z. SIREGAR ${ }^{3}$, NOOR F. HANEDA ${ }^{3}$, YUNIK \\ ISTIKORINI ${ }^{3}$, RIKA RAHMAWATI ${ }^{4}$, YAHYA AMIN ${ }^{4}$, ULFAH J. SIREGAR ${ }^{3, \vee v}$ \\ ${ }^{1}$ Program of Tropical Silviculture, Department of Silviculture, Faculty of Forestry and Environment, Institut Pertanian Bogor. Jl. Ulin Lingkar Akademik, \\ Dramaga, Bogor 16680, West Java, Indonesia. Tel./fax.: +62-251-8626806, `email: aditya_gembilnugroho@ apps.ipb.ac.id \\ ${ }^{2}$ Department Agronomy and Horticulture, Faculty of Agriculture, Institut Pertanian Bogor. Jl. Kamfer, Dramaga, Bogor 16680, West Java, Indonesia \\ ${ }^{3}$ Department of Silviculture, Faculty of Forestry and Environment, Institut Pertanian Bogor. Jl. Ulin Lingkar Akademik, Dramaga, Bogor 16680, West \\ Java, Indonesia. Tel./fax.: +62-251-8626806, "vemail: ulfahjs@apps.ipb.ac.id \\ ${ }^{4}$ Research and Development Center Perum Perhutani. Jl. Wonosari, Batokan, Tromol Pos 6, Cepu, Blora 58302, Central Java, Indonesia
}

Manuscript received: 21 February 2021. Revision accepted: 21 April 2021.

\begin{abstract}
Nugroho A, Matra DD, Siregar IZ, Haneda NF, Istikorini Y, Rahmawati R, Amin Y, Siregar UJ. 2021. Early growth evaluation and estimation of heritability in a sengon (Falcataria moluccana) progeny testing at Kediri, East Java, Indonesia. Biodiversitas 22: 2728-2736. Sengon (Falcataria moluccana) is widely cultivated as a monoculture plantation in community forests that still poses a high risk of pest and disease attacks. Although plants naturally show signs of resistance, there is still however a lack of understanding on the influence of relative plant resistance on growth due to environmental and genetic factors. This study was aimed to evaluate the early growth of a sengon progeny testing in Kediri, East Java and to estimate the genetic parameters with respect to its resistance and susceptibility to stem borer and rust disease. Progeny test was designed using randomized complete block design (RCBD) with four blocks as replications. Each block consists of 100 families which was grouped into two categories, 50 families for resistant group and 50 families for susceptible group. Observations were made at the age of 0 and 9 months after planting on 9 individuals per plot in each family. Growth characteristics were measured as germination (\%), height (m), and diameter (cm). Results indicated that the sengon growth rate from resistant and susceptible plant groups showed a significant difference. Heritability values are classified as moderate, ranging between 0.107 to 0.133 and 0.102 to 0.150 for height and diameter variables, respectively. These information may be used for gradual selection by considering the appropriate intensity.
\end{abstract}

Keywords: Genetic parameter, growth, heritability, progeny test, sengon

Abbreviations: FMU: Forest Management Unit; FMR: Forest Management Resort, MAP: Months After Planting

\section{INTRODUCTION}

Sengon (Falcataria moluccana (Miq.) Barneby \& J. Grimes) is a fast-growing species cultivated in plantations in Indonesia (Lelana et al. 2018; Rahayu et al. 2010; Rahmawati et al. 2019; Siregar 2007). Sengon has several notable properties, such as easy to cultivate, economically valuable, and is a type of legume that can fix nitrogen. The ability of legumes to fixate nitrogen has a positive influence on soil fertility Vanlauwe et al. (2019). Hence sengon species are widely used in reforestation and restoration programs (Iskandar and Ellen 2008). In 2019, the selling price of sengon sawn wood in Lampung is Rp $1,200,000$ (US\$ 92) per $\mathrm{m}^{3}$ (Utama et al. 2019). Sengon wood can be used for house construction materials (Rahmawati et al. 2019), wooden crates, matches, and raw pulp material (Siregar et al. 2007).

High demand for sengon wood each year led to the expansion of monoculture sengon plantations. The drawback of monoculture is that the plant community will be vulnerable to pest and disease attacks. The most frequent pests and diseases that attack sengon plantations are boktor stem borer (Xystrocera festiva) and gall rust disease (Endang and Haneda 2010; Siregar et al. 2019; Sunandar et al. 2017). Both these pests and disease types may simultaneously attack sengon, which initiate double losses (Darwiati and Anggraeni 2018). Therefore, to satisfy the growing industrial demand for sengon wood, a healthy and productive plantation must be established, particularly the one which has good resistance to pests and diseases. The use of high-quality seeds has been recommended to increase growth rate and resistance to pests and diseases. However, there is still a lack of seed sources established from a genetic trial for resistance to pests and diseases.

In 2020, a progeny trial plot at the Perum Perhutani Kediri Forest Management Unit (FMU) was established using 50 resistant plant families and 50 susceptible plant families to boktor stem borers and gall rust disease. The trial was made to obtain data and information on the growth rate of sengon plants and associated genetic parameters that affect their growth and resistance to pest and disease are lacking. The heritability is estimated based on a population of genetic testing (e.g. breeding population) and be used later for considering a gradual selection and evaluation to produce improved seeds (Zobel and Talbert 1984; Mashudi and Susanto 2016). This study 
aims to evaluate the early growth of sengon progeny testing in Kediri, East Java, and to estimate the genetic parameters with respect to its resistance and susceptibility to stem borer and rust disease. Our study is expected to provide information about early evaluation growth of sengon progeny trial for improving $F$. moluccana seeds that are relatively resistant from stem borer and gall rust.

\section{MATERIALS AND METHODS}

\section{Seed extraction and preparation}

The seeds of $F$. moluccana were collected from Jatirejo Forest Management Resort (FMR), Perum Perhutani, Kediri FMU in January 2018. The seeds were collected from 100 mother trees consisting of 50 boktor and gall rust-resistant plant groups and 50 susceptible plant groups (e.g. 17 boktor prone trees, 17 gall rust-prone trees, and 16 susceptible trees to both). Susceptible trees referred to those trees that were severely attacked by either boktor pest or gall rust, while resistant trees were the trees as control showing no signs of the pest and disease attacks
(Siregar et al. 2019). The seeds as control were extracted from adjacent trees and grow on the same plot to minimize environmental influences. The seeds from each family were then immersed in hot water $\left(80^{\circ} \mathrm{C}\right)$ for 5 minutes and then soaked in cold water for 24 hours as priming treatment. After that, the seeds from each family were sown in sowing boxes filled with sand in March 2020. After 14 days, the seedlings with a height of $5 \mathrm{~cm}$, having at least two leaves are transferred to polybags with a media mixture of soil, compost, and husk charcoal (2: 1: 1).

\section{Study area}

The sengon progeny trial plot is located in compartment 125D of the Pandantoyo FMR, Perum Perhutani Kediri FMU, East Java (07 56' 57" S, $112^{\circ} 11$ ' 42” E) (Figure 1). The plots are stationed at 461 masl with climate type C based on Schmidt and Ferguson, which has an average rainfall of $2.301 \mathrm{~mm} /$ year with two peaks of rainy seasons around January and December, and a dry period during July-August (Figure 2), the type of soil at the study site is latosol (Perum Perhutani 2015).

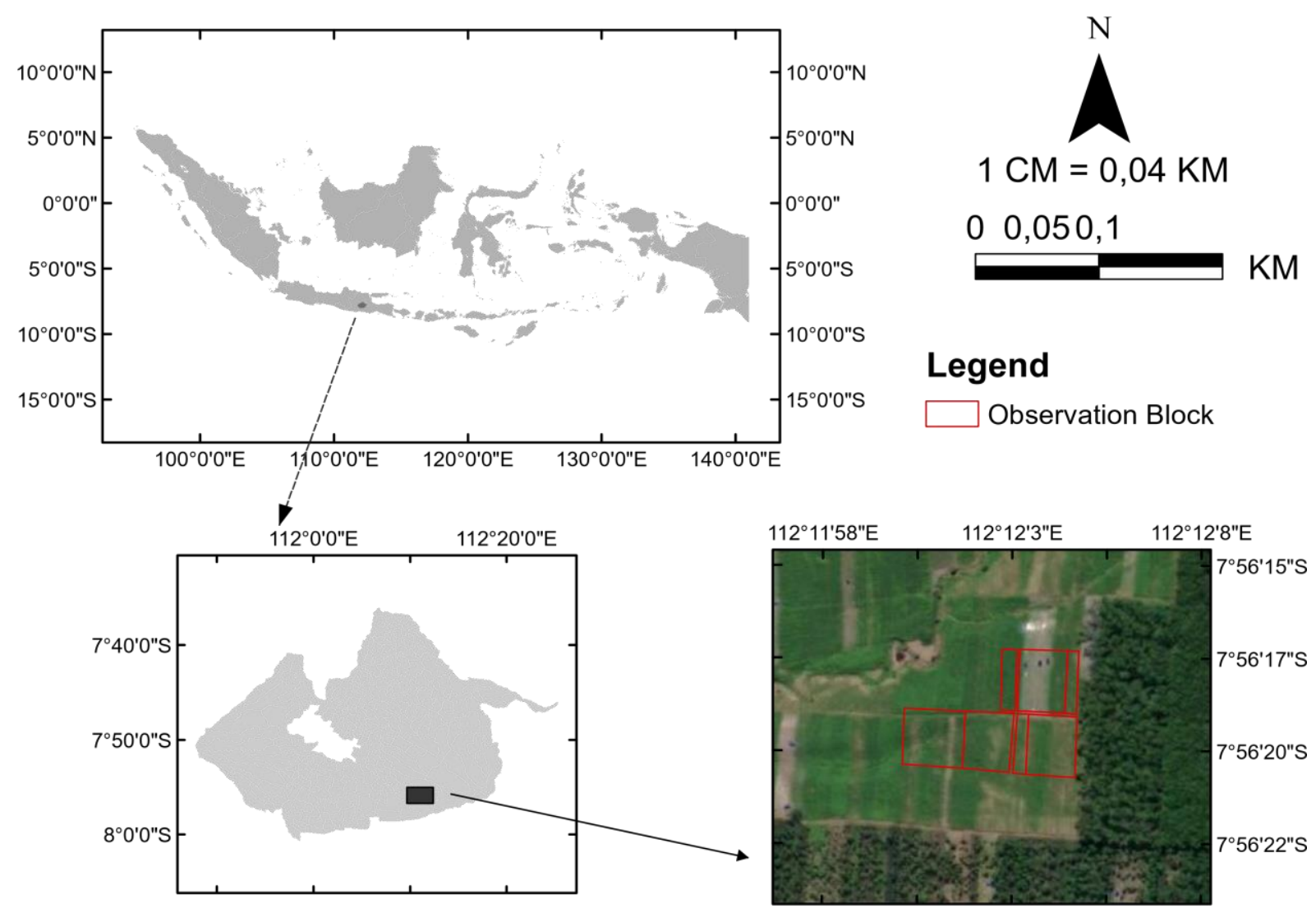

Figure 1. Location of sengon progeny testing plots in Perum Perhutani Kediri FMU, East Java, Indonesia 


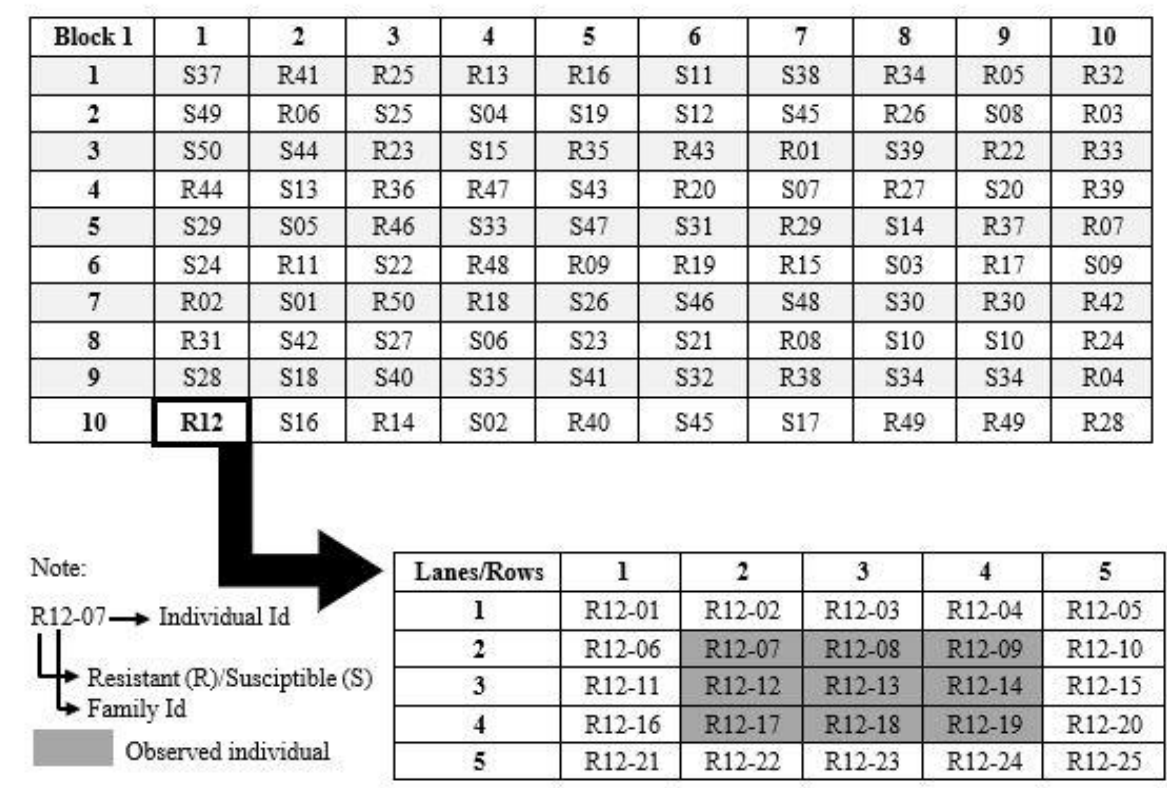

Figure 3. The layout of planting and collecting progeny data in block 1

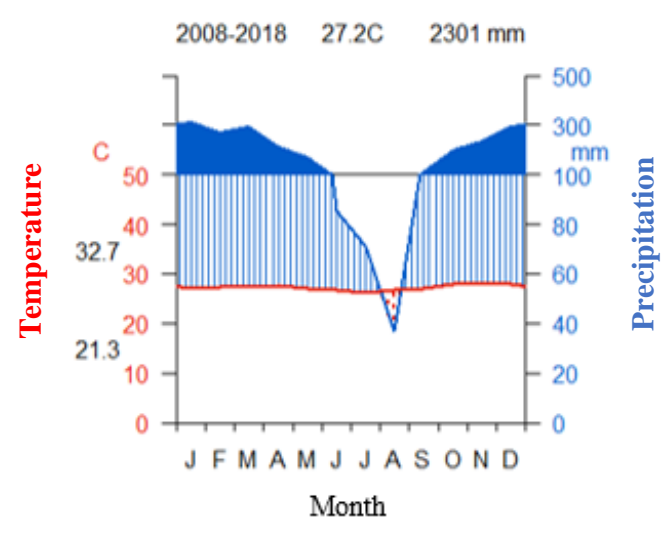

Figure 2. Average monthly temperature and precipitation at Kediri from 2008 to 2018. The relationship of average monthly precipitation (solid and striped blue) to average monthly temperature (red line).

\section{Experimental design}

Progeny test was designed using randomized complete block design (RCBD) with four blocks as replications. Each block consists of 100 families which was grouped into two categories, 50 families for resistant group and 50 families for susceptible group. The planting of seedlings used a spacing of $3 \mathrm{~m} \times 2 \mathrm{~m}$ with 25 tree square plots. However, observations were only made on inner 9 individual trees (Figure 3). Preparation of the planting area is carried out before planting. Area preparation activities include cleaning the area, making and installing stakes, making planting holes, and adding compost. Cleaning the planting area is carried out to remove shrubs, weeds, and previous plant debris. Furthermore, the soil is hoeed so that it is loose and easy to cultivate. The stake is made using bamboo, the length of the stake is 1 meter. The stake is fixed as a sign where the sengon seedlings must be planted, therefore fixed the stake must be in accordance with the specified spacing. The planting hole is made with a size of $20 \times 20 \times 20 \mathrm{~cm}$ right at the stake that has been fixed. For each planting hole, $2 \mathrm{~kg}$ of compost is added. The addition of compost is expected to increase the availability of organic matter in the soil.

\section{Character observed}

The study began with seed monitoring, the number of germinated seeds was recorded to calculate the germination rate (Sudrajat et al. 2015) of each family with the following formula:

$$
\mathrm{PG}=\frac{\Sigma N G I+\Sigma N G I I}{\sum T S} \times 100 \%
$$

Where: $\mathrm{PG}=$ percentage of germination, $\mathrm{NG} \mathrm{I}=$ Normal number of germinants on the first day of observation, NG II = number of normal germinants on the second day of observation, TS = Total number of seeds sown. Sengon plant growth properties measured in the progeny test plot were the diameter $(10 \mathrm{~cm}$ from the base of the stem) and plant height. The seedling diameter was measured using a caliper, while the height was measured using a measuring pole from the ground to the top of plants (apical). Diameter and height measurements were carried out in July 2020 and April 2021.

\section{Data analysis}

The data obtained were then analyzed to determine the average plant growth, diversity of traits among the families tested, estimated heritability values and genetic correlations between observed traits. Analysis of variance (ANOVA) using Agricole package ( $\mathrm{R}$ statistics) on each variable was carried out with the following statistical models: 
$\mathrm{Y}_{\mathrm{ijk} l}=\mu+\mathrm{B}_{\mathrm{i}}+\mathrm{R}_{\mathrm{j}}+\mathrm{F}(\mathrm{R})_{\mathrm{k}(\mathrm{j})}+\mathrm{BR}_{\mathrm{ij}}+\mathrm{BF}(\mathrm{R})_{\mathrm{ik}(\mathrm{j})}+\mathrm{E}_{\mathrm{l}(\mathrm{ijk})}$

where, Yijkl = observation in the 1-th individual of the $\mathrm{k}$-th family of the $\mathrm{j}$-th resistance in the $\mathrm{i}$-block; $\mu=$ means; $\mathrm{Bi}=$ random effect of block $\mathrm{i}(\mathrm{i}=1,2,3,4) ; \mathrm{Rj}=$ random effect of resistance $\mathrm{j}-(\mathrm{j}=$ resistance, susceptible $) ; \mathrm{F}(\mathrm{R}) \mathrm{k}(\mathrm{j})$ $=$ the $\mathrm{k}$-th family random effect $(\mathrm{k}=1,2, \ldots, 100)$ on the $\mathrm{jth}$ resistance; $\mathrm{BRij}=$ interaction effect between $\mathrm{i}$-th block and j-resistance; $B F(R)$ ik $(j)=$ the interaction between the I-th block and the k-th family in the $\mathrm{j}$-th resistance in the $\mathrm{j}$ block; El (ijk) = random effect of the 1-individual $(1=$ $1,2, \ldots, 9)$ the $\mathrm{k}$-th family on the $\mathrm{j}$-th resistance in the i-block.

\section{Genetic parameters}

Heritability is suspected from various component components (Falconer and Mackay 1996). The average heritability of individuals and families for each character is measured using the following formulas:

$$
h^{2} i=\frac{4 \sigma^{2} f}{\sigma^{2} e+\sigma^{2} f b+\sigma^{2} f} ; h^{2} f=\frac{\sigma^{2} f}{\frac{\sigma^{2} e}{b t}+\frac{\sigma^{2} f b}{t}+\sigma^{2} f}
$$

Where: $h^{2} \mathrm{i}=$ individual heritability, $\mathrm{h}^{2} \mathrm{f}=$ family heritability, $\sigma^{2} \mathrm{f}=$ family variety, $\sigma^{2} \mathrm{fb}=$ interaction range between family and block, $\sigma^{2} \mathrm{e}=$ residual range, $\mathrm{b}=$ number of blocks, $\mathrm{t}=$ number of blocks tree per plot.

Phenotypic and genetic correlations of the variance and covariance components are substituted into a standard formula for the moment product correlation coefficient:

$R p(x y)=\frac{\operatorname{CoVp}(x y)}{\sqrt{\sigma^{2} p+\sigma^{2} p(y)}} ; R g(x y)=\frac{\operatorname{Cov} f(x, y)}{\sqrt{\sigma^{2} f(x)+\sigma^{2} f(y)}}$

Where $\mathrm{x}=$ tree height; $\mathrm{y}=$ diameter; $\sigma^{2}(x)$ and $\sigma^{2} f(x)$ $=$ variance of phenotypic and genotypic products of $\mathrm{x}$ parameters; $\sigma^{2} p(y)$ and $\sigma^{2} f(y)=$ variance of the phenotypic and genotypic products of the parameter y; $\operatorname{COVP}(x y)$ and $\operatorname{COVf}(x, y)=$ the covariance component of the phenotypic and genotypic products of the parameters $\mathrm{x}$ and $\mathrm{y}$, respectively, while the covariance component of the properties of $\mathrm{x}$ and $\mathrm{y}$ is calculated by the formula (O'neill et al. 2001):

$$
\operatorname{coV} f\left(x_{x} y\right)=0.5\left(\sigma_{f(x+y)}^{2}-\sigma_{f(x)}^{2}-\sigma_{f(y)}^{2}\right.
$$

Where: $\sigma_{f(s}^{2}=$ Components of the various properties of $\mathrm{x}$ and $\mathrm{y}, \sigma=$ Variable components of the $\mathrm{x}$ family properties, $\sigma=$ Variable component of the y family.

\section{RESULTS AND DISCUSSION}

\section{Growth variation}

The critical aspect of the plant breeding program is variations. Variance analysis is carried out to see the information of the variability that occurs among tree growth factors. Variance analysis for height and diameter variables of the sengon plant are shown in Table 1 .
In the 0 MAP (months after planting) and 9 MAP sengon progeny test, the family, resistance, and interaction between block and resistance (resistant and susceptible) significantly affected both the height and diameter variables. The value of family and resistance variations indicates that the genetic variation expressed by sengon growth is relatively vast. A vast genetic variation will enable the selection process to produce better genotypes (Jalata et al. 2011). On the other hand, the interaction between block and resistance shows that the growth of sengon is not solely influenced by genetic factors but also by environmental factors.

The initial growth of resistant sengon plants has a higher average value than susceptible sengon plants for each variable (Figure 4). The resistant family group has average germination of $61.16 \%$ and $55.24 \%$ in the susceptible family group (Figure 4a). The mean plant heights at 0 MAP and 9 MAP for resistant and susceptible groups were $0.64 \mathrm{~m}, 3.50 \mathrm{~m}, 0.53 \mathrm{~m}$, and $3.07 \mathrm{~m}$, respectively (Figure 4b). Meanwhile, the average plant diameter was $1.57 \mathrm{~cm}, 3.24 \mathrm{~cm}, 1.27 \mathrm{~cm}$, and $2.83 \mathrm{~cm}$, respectively (Figure $4 \mathrm{c}$ ).

\section{Top ten family}

Each family of the two populations group has a different growth rate. The ranking is an essential aspect of plant breeding programs because it shows the performance of each family which can later be used for the selection process. We separated the best families from the resistant and susceptible groups. Table 2 and Table 3 presents the results of the ten best families for the observed variables. The prominent families for the germination rate variable, R33 and S3 families possess the highest average value. In the height variable, the family was consistent into the top ten families at the age of 0 MAP and 9 MAP, namely R4, $\mathrm{R} 12$, and S25. On the other hand, R12, R4, R15, S25, and $\mathrm{S} 27$ families consistently had the top ten average in respect of diameter.

Table 1. Mean square for growth performance in sengon progeny test

\begin{tabular}{lllll}
\hline Age & $\begin{array}{l}\text { Source of } \\
\text { variation }\end{array}$ & $\begin{array}{c}\text { Degree of } \\
\text { freedom }\end{array}$ & $\begin{array}{c}\text { Height } \\
(\mathbf{m})\end{array}$ & $\begin{array}{c}\text { Diameter } \\
(\mathbf{c m})\end{array}$ \\
\hline 0 MAP Resistance & 1 & $10.029^{* *}$ & $8.315^{* *}$ \\
Block & 3 & $0.266^{* *}$ & $0.035^{*}$ \\
Family(Resistance) & 99 & $0.944^{* *}$ & $0.427^{* *}$ \\
Block* Resistance & 3 & $0.027^{*}$ & $0.212^{* *}$ \\
Block*Family(Resistance) $)$ & 297 & $0.017^{* *}$ & $0.057^{* *}$ \\
Error & 3200 & 0.010 & 0.006 \\
9 MAP Resistance & 1 & $39.468^{* *}$ & $40.710^{* *}$ \\
Block & 3 & $5.821^{* *}$ & $9.785^{* *}$ \\
Family(Resistance) & 99 & $1.632^{* *}$ & $1.926^{* *}$ \\
Block* Resistance & 3 & $1.509^{* *}$ & $1.030^{* *}$ \\
Block*Family(Resistance) & 297 & $1.305^{\mathrm{ns}}$ & $1.628^{\mathrm{ns}}$ \\
Error & 3200 & 0.639 & 0.570 \\
\hline
\end{tabular}

Note: $* *=$ highly significant at $p<0.01, *=$ significant at $p<0.05$, $\mathrm{ns}=$ not significant, MAP $=$ months after planting 


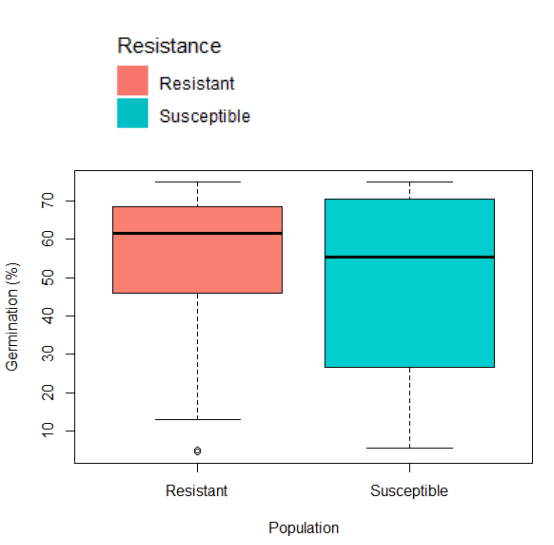

A

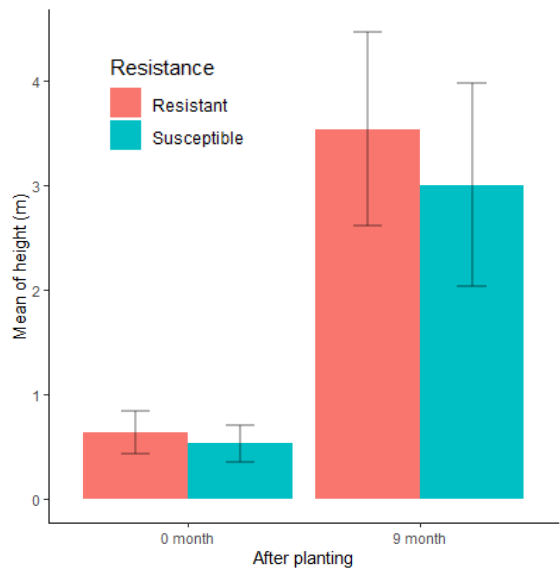

B

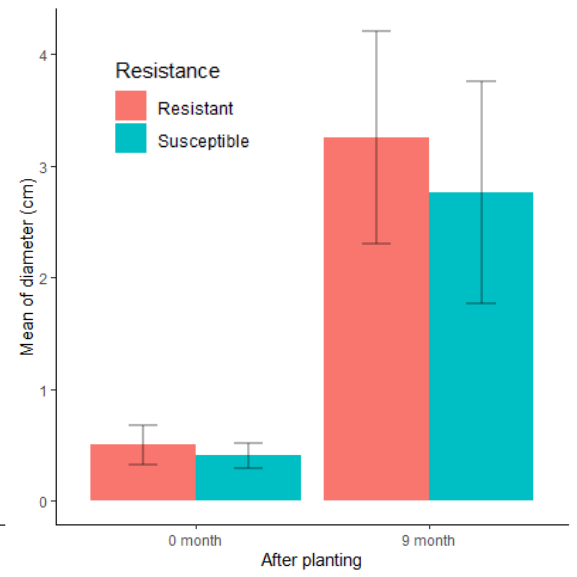

C

Figure 4. Performance of plant growth in sengon progeny test: A. Germination percentage, B. Height, C. Diameter

\section{Genetic parameters}

Estimation of heritability value is required to obtain information on the proportion of genetic factors contribution passed down from the main plant to its progeny. Heritability value is obtained from a comparison between the additive variants and the total phenotypic variants. The approximation of family heritability $\left(\mathrm{h}_{\mathrm{f}}\right)$ on height and diameter variables is higher than individual heritability $\left(\mathrm{h}_{\mathrm{i}}\right)$, further illustrated in Table 4 . Heritabilities estimation in this study ranged from 0.102 to 0.150 . Cotterill and Dean (1990), state that the heritability is considered high should the value is more than 0.3 , for moderate heritability is between 0.1 to 0.3 , and low heritability is less than 0.1 .

Besides heritability value, the selection process in the progeny test is affected by genetic correlations between traits. This value is essential in determining the prediction of the influence and the effectiveness of a trait selection. Table 5 shows that the phenotypic correlation gives a greater value than the genetic correlation between the height and diameter variables of the sengon progeny test.

\section{Discussion}

Growth is the process of increasing the size of organic system forms (Azizah et al. 2019). Plant growth is influenced by several aspects such as genetic information, environmental condition, and interactions of internal or external factors. The variables of germination rate, height, and diameter of resistant and susceptible sengon group displayed existing variations among families. The observed differences in growth rate presumably due to differences in the genetic material used. Johnson and Lenhard (2011) stated that plant growth is controlled by genetics, thus differences in genetic formation will affect the appearance of a particular character. Analysis of genetic diversity using RAPD, SSR, and SNP markers showed grouping between susceptible and resistant sengon plants (Shabrina 2020; Rahmawati 2017; Siregar et al. 2019; Yuskianti and Shiraishi 2017). Shabrina et al. (2019a) supported this result, which found variances in gene expression in prime sengon plants against sengon plants with gall rust through differential expression gene (DEG) analysis. The results of this study indicate that there is an expression of growth inhibitor genes in plants infected by gall rust, such as Retrovirus-related Pol polyprotein from transposon RE2 which plays a role in the synthesis of aspartic protease leads to dwarfing phenomenon in plants (Xia et al. 2004) and Cytokinin dehydrogenase causing cytokinin deficiency in plant tissue (Werner et al. 2003). Whereas in resistant plants group, transcription factor and Ubiquitin carboxylterminal hydrolase 13 genes were found which have a role in plant resistance to pathogens (Shabrina et al. 2019b).

Table 2. The ten prominent families based on the variables of germination rate in sengon progeny test

\begin{tabular}{ccc}
\hline Ranking & Resistant group & Susceptible group \\
\hline 1 & R33 (75) & S3 (75) \\
2 & R37 (75) & S5 (75) \\
3 & R22 (73.5) & S8 (75) \\
4 & R13(73) & S15 (75) \\
5 & R8 (72.5) & S16 (75) \\
6 & R4 (72) & S21 (75) \\
7 & R19 (72) & S23 (75) \\
8 & R6 (71.5) & S35 (75) \\
9 & R20 (71.5) & S17 (74) \\
10 & R27 (71.5) & S13 (73) \\
\hline
\end{tabular}


Table 3. The ten prominent families based on the variables of height and diameter in the sengon progeny test

\begin{tabular}{|c|c|c|c|c|c|}
\hline & \multirow{2}{*}{ Ranking } & \multicolumn{2}{|c|}{ Resistant group } & \multicolumn{2}{|c|}{ Susceptible group } \\
\hline & & Height (m) & Diameter (cm) & Height (m) & Diameter $(\mathrm{cm})$ \\
\hline \multirow[t]{10}{*}{0 MAP } & 1 & $\mathrm{R} 10$ (1.11a) & R9 (0.74a) & S45 (0.93a) & S45 (0.68a) \\
\hline & 2 & $\mathrm{R} 9(1.06 \mathrm{a})$ & $\mathrm{R} 8(0.70 \mathrm{~b})$ & $\mathrm{S} 25(0.78 \mathrm{~b})$ & $\mathrm{S} 38(0.67 \mathrm{abc})$ \\
\hline & 3 & $\mathrm{R} 16$ (0.97b) & $\mathrm{R} 12(0.68 \mathrm{~b})$ & $\mathrm{S} 35(0.75 \mathrm{cb})$ & $\mathrm{S} 25$ (0.67abc) \\
\hline & 4 & $\mathrm{R} 8(0.97 \mathrm{~b})$ & $\mathrm{R} 10(0.67 b)$ & $\mathrm{S} 26(0.75 \mathrm{cb})$ & S27 (0.66abcd) \\
\hline & 5 & $\mathrm{R} 12(0.90 \mathrm{c})$ & R6 (0.67c) & $\mathrm{S} 27(0.75 \mathrm{cb})$ & S26 (0.65abcd) \\
\hline & 6 & $\mathrm{R} 11$ (0.86cd) & $\mathrm{R} 11(0.62 \mathrm{c})$ & $\mathrm{S} 44(0.74 \mathrm{cb})$ & S44 (0.65bcd) \\
\hline & 7 & R17 (0.86cd) & R4 (0.61d) & $\mathrm{S} 24(0.73 \mathrm{~cd})$ & S36 (0.65bcd) \\
\hline & 8 & R6 (0.83de) & R15 (0.60ed) & $\mathrm{S} 36(0.72 \mathrm{~cd})$ & S35 (0.65bcd) \\
\hline & 9 & R23 (0.80fe) & R16 (0.58edf) & $\mathrm{S} 32(0.72 \mathrm{~cd})$ & S32 (0.65bcd) \\
\hline & 10 & R4 (0.76fg) & R23 (0.58fg) & S4 (0.69de) & S4 (0.65bcd) \\
\hline \multirow[t]{10}{*}{9 MAP } & 1 & $\mathrm{R} 24(3.34 \mathrm{a})$ & R24 (3.41a) & $\mathrm{S} 23(3.18 \mathrm{a})$ & S7 (3.26a) \\
\hline & 2 & R32 (2.91ab) & R39 (3.31a) & S47 (2.97a) & S5 (3.16ab) \\
\hline & 3 & R39 (2.83ab) & $\mathrm{R} 4$ (3.22ab) & S7 (2.96b) & $\mathrm{S} 25$ (3.13abc) \\
\hline & 4 & $\mathrm{R} 4(2.77 \mathrm{~b})$ & R32 (2.83ab) & $\mathrm{S} 28(2.86 \mathrm{~b})$ & $\mathrm{S} 47(3.12 \mathrm{bc})$ \\
\hline & 5 & R30 (2.76b) & $\mathrm{R} 30(2.82 \mathrm{~b})$ & $\mathrm{S} 15(2.79 \mathrm{c})$ & $\mathrm{S} 15$ (3.00bc) \\
\hline & 6 & R47 (2.69bc) & $\mathrm{R} 12$ (2.75bc) & S5 (2.68cd) & $\mathrm{S} 49(2.81 \mathrm{~d})$ \\
\hline & 7 & $\mathrm{R} 15$ (2.60c) & $\mathrm{R} 47(2.75 \mathrm{c})$ & $\mathrm{S} 19(2.61 \mathrm{~d})$ & $\mathrm{S} 13$ (2.81de) \\
\hline & 8 & $\mathrm{R} 40$ (2.49cd) & R15 (2.73de) & $\mathrm{S} 25$ (2.56de) & S28 (2.80def) \\
\hline & 9 & R36 (2.49cd) & R36 (2.69e) & $\mathrm{S} 50$ (2.46de) & $\mathrm{S} 27(2.63 \mathrm{e})$ \\
\hline & 10 & $\mathrm{R} 12(2.48 \mathrm{e})$ & R49 (2.67f) & $\mathrm{S} 10(2.39 \mathrm{f})$ & S37 (2.56ef) \\
\hline
\end{tabular}

Note: The mean value followed by a different superscript on the same columns is significantly different $(\mathrm{P}<0.05)$, MAP $=$ months after planting

Table 4. Estimated heritability in sengon progeny test

\begin{tabular}{ccccc}
\hline \multirow{2}{*}{ Age } & \multicolumn{2}{c}{$\begin{array}{c}\text { Individual heritability } \\
\left(\boldsymbol{h}^{2} \boldsymbol{i}\right)\end{array}$} & \multicolumn{2}{c}{$\begin{array}{c}\text { Family heritability } \\
\left(\boldsymbol{h}^{2} \boldsymbol{f}\right)\end{array}$} \\
\cline { 2 - 5 } & Height & Diameter & Height & Diameter \\
\hline 0 MAP & 0.129 & 0.137 & 0.133 & 0.150 \\
9 MAP & 0.114 & 0.102 & 0.131 & 0.107 \\
\hline
\end{tabular}

Table 5. Coefficient of genetic correlation (upper diagonal) and phenotypic (lower diagonal) between variables in sengon progeny test

\begin{tabular}{lcccc}
\hline & \multicolumn{2}{c}{ 0 MAP } & \multicolumn{2}{c}{ 9 MAP } \\
\cline { 2 - 5 } & Height & Diameter & Height & Diameter \\
\hline Height & - & 0.311 & - & 0.130 \\
Diameter & 0.506 & - & 0.693 & - \\
\hline
\end{tabular}

The height and diameter measurement results for both resistant and susceptible sengon groups in this study showed a growth rate in line with age. Hadiyan (2010a) reported that the growth of 4-month-old sengon in Cikampek, West Java, which had the highest average height of $1.98 \mathrm{~m}$ and diameter of $0.93 \mathrm{~cm}$. At 12-monthsold showed an average height of $2.37 \mathrm{~m}$ and a diameter of $4.15 \mathrm{~cm}$ (Hadiyan 2010b). Besides being influenced by the genetic material, the variations in the measured variables are influenced by the condition of the research location. Sengon requires a wet climate and loose soil to support its growth (Krisnawati et al. 2011). While differences in the germination rate of each family assumably due to the diversity in seed quality. According to Yuniarti et al. (2013) and Suharsi et al. (2016), seed quality is influenced by its physical, physiological, and genetic quality. Seed originating from a non-breeding mother tree will produce seeds with low viability. The results of the observation of germination showed that the highest percentage germinated was only $75 \%$ (Table 2). The seeds used are seeds that have been stored for 25 months. According to Baskorowati et al. (2017a), a long storage time will reduce the viability of seeds. This happens because during the storage process, the seeds will experience deterioration which causes a decrease in the quality of the seeds.

Seeds family, resistance, and interaction between block and resistance significantly influence both the height and diameter variables. A similar result was found in the 12 months after planting $F$. moluccana (Hardiyanto 2012), 11 months after planting E. urophylla (Sumardi et al. 2016), and 12 and 54 months after planting N. cadamba (Sudrajat et al. 2016). The value of family variation shows the level of genetic variation of the main tree. Family, resistance, and interaction between block and resistance indicate that the genetic variation expressed by sengon growth is relatively vast. According to Hamrick et al. (1992), species that interbreed with high genetic variation in species and populations in general. Genetic variations are required to improve the adaptability of plants to new environments or pests and diseases (Rahayu et al. 2010).

This study found ten prominent families as shown in Table 3. Family R4 and R12 have been admitted to be the finest family to breed because the two families are always included in the top ten on all variables. Also, R4 and R12 sengon families can be considered to select mother tree candidates. Mahfudz et al. (2010) describe that variations 
in the traits of height and diameter growth at the family level are strongly influenced by genetic factors. Thus, traits of plant height and diameter are used as selection criteria for obtaining a productive sengon plant breed that is resistant to pests and diseases. While families with poor growth rates become the plant candidates intended for thinning activities. Thinning will reduce competition between plants and trigger a significant increase in plant growth (Kang et al. 2014; Gradel et al. 2017).

The heritability estimation value in this study was categorized as moderate for height and diameter variables (Table 4). Heritabilities illustrate the proportion of various phenotypic traits associated with genetic effects and are used as a parameter of previous mother tree phenotypes diversity that might be inherited in the next progeny (Edwards 2018). Heritability values ranged from 0 to 1 . If the heritability value is close to 1 (one), it means that heritability is high, meaning that genetic factors influence the character's appearance. If the heritability value is close to 0 (null), heritability is low, meaning the character's appearance is influenced by environmental factors (Anna et al. 2020). Family heritability values were found to be greater than individual heritability values (Table 4), indicating that the probability of genetic acquisition would be higher by the selection process between families rather than individual selection. As plants age, their heritability tends to decrease. Rahayu et al. (2020) reported that the individual heritability values for the height of the two months after planting sengon plant were 0.79 and 0.14 in the three months after planting, whereas Setiadi et al. (2014) reported that at eight months after planting sengon plant the heritability was 0.08 . Decreasing heritability value during the increasing plant lifetime is due to the phenotype diversity rate of additional diversity (Surles et al. 1995). Besides being affected by plant maturity, heritability is also influenced by the number of experimental units (individuals per family) and the number of replications/blocks. Greater experimental and test units in the total lead to greater heritability value (Russel and Libby 1986).

The correlation of phenotypes and genotypes between height and diameter characters has positive values. Comparable results were found in 6-months after planting E. cloeziana (Li et al. 2016), 12 (Hardiyanto 2012) and 18 months after planting (Baskorowati et al. 2017b) $F$. moluccana and 54 months after planting $N$. cadamba (Chaerani et al. 2019). This reflects a linear relationship, an increase will consecutively follow the plant height variable in diameter value. According to Sudrajat et al. (2015), a greater phenotypic correlation value than genetic correlation explains that breed selection will be more effective with height and diameter traits are combined into account. Plant diameter and height are satisfactory criteria in tree breeding programs (Mulyadiana et al. 2020).

The 0 MAP and 9 MAP sengon growth of resistant and susceptible plant groups demonstrate a significant difference. Heritability values are classified as moderate in the category, with heritability values in height variable ranging between 0.129 to 0.133 (0 MAP) and 0.114 to 0.131 (9 MAP), 0.137 to 0.150 (0 MAP) and 0.102 to 0.107
(9 MAP) in diameter variables. The correlation of phenotypes and genotypes between height and diameter characters has positive values. These information may be used for gradual selection by considering the appropriate intensity. Future research is suggested to repeat the study to progeny test the $F$. moluccana using a similar method at an older age.

\section{ACKNOWLEDGEMENTS}

This research is a collaboration funded by the Ministry of Education and Culture, Directorate General of Higher Education of the Republic of Indonesia with the scheme of Penelitian Pendidikan Magister menuju Doktor untuk Sarjana Unggul (PMDSU) based on contract number: 200/SP2H/PMDSU/DRPM/2020, Penelitian Dasar Unggulan Perguruan Tinggi (PDUPT) based on contract numbers: 1/AMD/E1/KP.PTNBH/2020, SEAMEO BIOTROP, and Perum Perhutani. We also thank Perum Perhutani KPH Kediri for technical support in the field.

\section{REFERENCES}

Anna N, Supriyanto, Karlinasari L, Sudrajat DJ, Siregar IZ. 2020. The growth, pilodyn penetration, and wood properties of 12 Neolamarckia cadamba provenances at 42 months old. Biodiversitas 21 (3): 10911100. DOI: $10.13057 /$ biodiv/d210332

Azizah N, Wijayanto N, Wirnas D. 2019. The growth and rooting dimensions of the local and Solomon albizia in the agroforestry system. Biodiversitas 20 (10): 3018-3023. DOI: 10.13057/biodiv/d201034

Baskorowati L, Setiadi D, Fauzi MA. 2017. Seed viability of sengon after 6 months and 23 years storage. Proceeding of National Seminar on Biology and Science Education II. Muhammadiyah Surakarta University, Surakarta, 20 May 2017. [Indonesian]

Baskorowati L, Bush D, Setiadi D, Susanto M. 2017. Genetic variation of growth and disease resistance trait in open-pollinated provenanceprogeny trial of Falcataria moluccana growing on two rust-affected site at age 18 monts. J Manajeman Hutan Tropika 23 (1): 1-7. DOI: 10.7226/jtfm.23.1.1 [Indonesian]

Bello OB, Ige SA, Azeez MA, Afolabi MS, Abdulmaliq SY, Mahamood J. 2012. Heritability and genetic advance for grain yield and its component characters in maize (Zea mays L.). Int J Plant Res 2 (5): 138-145. DOI: 10.5923/j.plant.20120205.01

Chaerani N, Sudrajat DJ, Siregar IZ, Siregar UJ. 2019. Growth performance and wood quality of white jabon (Neolamarckia cadamba) progeny testing at Parung Panjang, Bogor, Indonesia. Biodiversitas 20 (8): 2295-2301. DOI: 10.13057/biodiv/d200826

Cotterill PP, Dean CA. 1990. Successful tree breeding with index selection. CSIRO Division of Forestry and Forest Product, Australia.

Darwiati W, Anggraeni I. 2018. The boktor and tumor attack at sengon in the plantation of tea Ciater. Jurnal Sains Natural 8 (2): 59-69. DOI: 10.31938/jsn.v8i2.119 [Indonesian]

Edwards S. 2018. Estimating heritability of pest resistance in forest trees: exploring potential biases from methodological and ecological factors. [Dissertation]. University of New Brunswick, Saint John.

Endang AH, Haneda HF. 2010. Infestation of Xystrocera festiva in Paraserianthes falcataria plantation in East Java, Indonesia. J Trop For Sci 22 (4): 397-402.

Falconer DS, Mackay TFC. 1996. Introduction to Quantitative Genetics 4nd Edition. Addison Wesley Longman Ltd, New York.

Gradel A, Ammer C, Ganbaatar B, Nadaldorj, Dovdondemberel B, Wagner S. 2017. On the effect of thinning on tree growth and stand structure of white birch (Betula platyphylla Sukaczev) and Siberian larch (Larix sibirica Ladeb.) in Mongolia. Forest 8: 105-128. DOI: 10.3390/f8040105 
Hadiyan Y. 2010a. Early growth evaluation of sengon (Falcataria moluccana) seedling seed orchard at 4 months of age in Cikampek, West Java. J Penelitian Tanaman Hutan 7 (2): 85-71. DOI: 10.20886/jpht.2010.7.2.85-91 [Indonesian]

Hadiyan Y. 2010b. Growth and genetic parameters of Falcataria moluccana progeny test at Cikampek West Java. J Penelitian Tanaman Hutan4 (2): 101-108. DOI: 10.20886/jpth.2010.4.2.101108. [Indonesian]

Hamrick JL, Godt MJ, Sherman-Broyles SL. 1992. Factors influencing levels of genetic diversity in woody plant species. New For 6: 95-124 DOI: 10.1007/978-94-011-2815-5 7

Hardiyanto EB. 2012. Genetic parameter estimates for growth in a progeny test of sengon (Falcataria moluccana) in Jember, East Java. Biota 17 (3): 1-7. DOI: 10.24002/biota.v17i3.144

Iskandar J, Ellen FR. 2008. The contribution of Paraserianthes falcataria (Albizia) to sustainable swidden management practices among the Baduy of West Java. Hum Ecol 28: 1-17.

Jalata Z, Ayana A, Zeleke H. 2011. Variability, heritabilty, and genetic advance for some yield and yield related traits in ethiopian barley (Hordum vulgare L.) landraces and crosses. Int J Plant Breed Genet. 5(1): 44-52.

Johnson K, Lenhard M. 2011. Genetic control of plant organ growth. New Phytol 191: 319-333. DOI: 10.1111/j.1469-8137.2011.03737.x

Kang JS, Shibuya M, Shin CS. 2014. The effect of forest-thining works on tree growth and forest environment. For Sci Technol 10 (1): 33-39. DOI: $10.1080 / 21580103.2013 .821958$

Krisnawati H, Varis E, Kallio M, Kanninen M. 2011 Paraserienthes falcataria (L.) Nielsen: Ecology, Silviculture and Productivity. CIFOR, Bogor. [Indonesian]

Lelana NE, Wiyono S, Giyanto G, Siregar IZ. 2018. Genetic diversity of Falcataria moluccana and its relationship to the resistance of gall rust disease. Biodiversitas 19 (1): 12-17. DOI: 10.13057/biodiv/d190102

Lelana NE, Wiyono S, Giyanto G, Siregar IZ. 2018. Cultivation Practices and Its Correlation to The Severity of Gall Rust Disease on Falcataria moluccana (Miq.) Barneby \& J.W. Grimes). JPHT 15 (1) 29-41. DOI: 10.20886/jpht.2018.15.1.29-41 [Indonesian]

Li C, Weng Q, Chen JB, Li M, Zhou C, Chen S, Zhou W, Guo D, Lu C, Chen JC, Xiang D, Gan S. 2016. Genetic parameter for growth and wood mechanical properties in Eucalyptus cloeziana F. Muell. New For 48 (1): 33-49. DOI: 10.1007/s11056-016-9554-4.

Mahfudz, Na'iem M, Sumardi, Hardiyanto EB. 2010. Growth variations in progeny test of Merbau (Intsia bijuga O'Ktze) in Sobang, Banten. JPTH 4 (3): 157-165. DOI: 10.20886/jpth.2010.4.3.157-165. [Indonesian]

Mashudi, Susanto M. 2016. Evaluation of Alstonia angustiloba Miq progeny trial at three years old at Wonogiri, Central Java. JPTH 10 (2): 83-94. DOI: 10.20886/jpth.2016.10.2.83-94. [Indonesian]

Mulyadiana A, Trikosoemaningtyas, Siregar IZ. 2020. Evaluation of early growth performance of 41 clone of teak (Tectona grandis Linn. f.) a four microsites in Purwakarta, Indonesia. J For Res 31 (3): 901-907. DOI: $10.1007 / \mathrm{s} 11676-019-00878-0$.

O'Neill N T, Dubovik O, Eck TF. 2001. A modified Angstrom coefficien for the characterization of sub-micron aerosols. App Opt 40 (15): 2368-2374. DOI: 10.1364/AO.40.002368.

Perum Perhutani. 2015. Management Plan for Conservation of FMU Kediri Results. Perum Perhutani, Kediri. [Indonesian]

Rahayu S, Lee SS, Shukor NAA. 2010. Uromycladium tepperianum, the gall rust fungus from Falcataria moluccana in Malaysia and Indonesia. Mycoscience 51: 149-153. DOI: 10.1007/S10267-0090022-2.

Rahayu S, Shukor NAA, Saleh G, Lee SS. 2020. Heritability of early growth traits and their genetic correlations for gall rust disease of Falcataria moluccana. Pak J Phytopathol 32 (01): 53-60. DOI: 10.33866/phytopathol.032.01.0553.

Rahmawati D. 2017. Evaluation of morphological, phytochemical, genetic characteristics of sengon (Falcataria moluccana) resistant and susceptible to gall rust [Thesis]. IPB University, Bogor. [Indonesian]

Rahmawati D, Khumaida N, Siregar UJ. 2019. Morphological and phytochemical characterization of susceptible and resistant sengon (Falcataria moluccana) tree to gall rust disease. Biodiversitas 20 (3) 907-913. DOI: 10.13057/biodiv/d200340.

Riany F, Siregar IZ, Sudrajat DJ. 2018. The growth and genetic potential of Gempol (Nauclea orientalis L.) as shading trees in urban landscapes; Proceeding of The International Symposium on Arboriculture in the Tropics: Securing Ecosystem Functions in Urban
Landscape. Bogor, 21 November 2017. DOI: 10.1088/17551315/203/1/012002

Russell JH, Libby WJ. 1986. Clonal testing efficiency: the trade-off between clone tested and ramet per clone. Can J Forest Res 16: $925-$ 930. DOI: $10.1139 / \times 86-164$.

Setiadi D, Susanto M, Baskorowati L. 2014. Gall rust disease defense attacks at progeny test of Falcataria moluccana in Bondowoso, East Java. J Penyakit Hama Tumbuhan 8 (1): 1-13. [Indonesian]

Shabrina H. 2020. Ecological Genomic Approach to Sengon Breeding (Falcataria moluccana) Resistant from Gall-Rust (Uromycladium falcatarium). [Dissertation]. IPB University, Bogor. [Indonesian]

Shabrina H, Siregar UJ, Matra DD, Kamiya K, Siregar I. 2019a. Short communication: DNA extraction from stored wood of Falcataria moluccana suitable for barcoding analysis. Biodiversitas 20 (6): 1748-1752. DOI: 10.13057/biodiv/d200635

Shabrina H, Ulfah UJ, Matra DD, Siregar IZ. 2019b. The dataset of De novo transcriptome assembly of Falcataria moluccana cambium from gall-rust (Uromycladium falcatarium) infected and non-infected tree. Data in Brief 26: 104489. DOI: 10.1016/j.dib.2019.104489.

Siregar UJ, Rachmi A, Massijaya MY, Ishibashi I, Ando K. 2007. Economic analysis of sengon (Paraserianthes falcataria) community forest plantation, a fast-growing species in East Java, Indonesia. For Policy Econ 9: 822-829. DOI: 10.1016/j.forpol.2006.03.014.

Siregar UJ, Rahmawati D, Damayanti A. 2019. Fingerprinting sengon (Falcataria moluccana) accessions resistant to boktor pest and gall rust disease using microsatellite markers. Biodiversitas 20 (9): 26982706. DOI: 10.13057/biodiv/d200935

Sudrajat DJ. 2015. Population diversity, provenance and adaptability test of (Neolamarckia cadamba (Roxb.) BOSSER). [Dissertation]. IPB University, Bogor. [Indonesina]

Sudrajat DJ, Nurhasybi, Bramasto Y. 2015. Testing Standards and Quality of Forest Plant Seeds. Forda Press, Bogor. [Indonesian]

Sudrajat DJ, Siregar IZ, Siregar UJ, Nurhasybi, Mansur I, Khumaida N. 2016. Intraspecific variation on early growth of Neolamarckia cadamba Miq. in provenance-progeny tests in West Java Province. Biotropia 23 (1): 10-20. DOI: 10.11598/btb.2016.23.1.439.

Suharsi TK, Syukur M, Wijaya AR. 2016. Fruit characterization and determination of seed physiological maturity of several chili (Capsicum annuum) genotypes. J Agron Indones 43 (3): 207-212. DOI: 10.24831/jai.v43i3.11246. [Indonesian]

Sumardi, Kurniawan H, Prastyono. 2016. Genetic parameter estimates for growth traits in an Eucalyptus urophylla S.T Blake progeny test in Timor Island. Indon J For Res 3 (2): 119-127. DOI: 10.20886/ijfr.2016.3.2.119-127

Sunandar A, Dorly, Supena EDJ. 2017. Induction of somatic embryogenesis in sengon (Falcataria moluccana) with thidiazuron and light treatments. Hayati J Biosci 24 (2): 105-108.

Surles SE, White TL, Hodge GR. 1995. Genetic parameter estimates for seedling dry weight traits and their relationship with parental breeding values in slash pine. For Sci 41: 546-563.

Syukur M, Sujiprihati S, Yunianti R, Kusumah DA. 2011. Estimation of genetic variability and character heritability of the yield components of several chili genotypes. J Agrivigor 10: 148-156.

Utama RC, Febryano IG, Herwanti S, Hidayat W. 2019. Marketing channels of sengon (Falcataria moluccana) on the local community sawn timber industry in Sukamarga Village, Abung Tinggi Subdistrict, North Lampung District. J Silva Lestari 7 (2): 193-203. DOI: $10.23960 /$ jsl27195-203. [Indonesian]

Vanlauwe B, Hungria M, Kanampiu F, Giller K E. 2019. The role of legumes in the sustainable intensification of African smallholder agriculture: Lessons learnt and challenges for the future. Agric Ecosyst Environ 284: 106583. DOI: 10.1016/j.agee.2019.106583.

Werner T, Motyka V, Laucou V, Smets R., Van Onckelen H, Schmülling T. 2003. Cytokinin-deficient transgenic Arabidopsis plants show multiple developmental alterations indicating opposite functions of cytokinins in the regulation of shoot and root meristem activity. Plant Cell 15: 2532-2550. DOI: 10.1105/tpc.014928.

Xia Y, Suzuki H, Borevitz J, Blount J, Guo Z, Patel K, Dizon RA, Lamb C. 2004. An extracellular aspartic protease functions in Arabidopsis disease resistance signaling. EMBO J 23 (4): 980-988. DOI: 10.1038/sj.emboj.7600086

Yuniarti N, Megawati, Leksono B. 2013. The influence of seed extraction method and seed size for maintaining for physical and physiological of Acacia crassicarp. J Penelitian Hutan Tanaman 10 (3): 129-137. DOI: 10.20886/jpht.2013.10.3.129-137 [Indonesian] 
Yuskianti V, Shiraishi S. 2017. Genetic diversity of sengon (Falcataria moluccana (Miq.) Barneby and J.W. Grimes) revealed using single nucleotide polymorphism (SNP) markers. Indon J For Res 4 (2): 85 94. DOI: $10.20886 /$ ijfr.2017.4.2.85-94.
Zobel B, Talbert J. 1984. Applied Forest Tree Improvement. Waveland Press, Illinois. 